の混合物である1ので，結昆を遠心分雔器で分離し，エーテルで 十分洗い、ヨウ化メチルと反応させた。この場合アンモニウム㙉 とキサントゲン酸エステルとの反応でスルフィドが生じる反応が はやくり，図6のように曲線となったので，時閔０の点で接線を 引き初速度を求めた。

\section{3 アンモニウム塩の分析}

反応によって生成したアンモニウム塩はエーテルで十分洗津 し, 減圧下に乾燥し, 融点, 分子量20)を測定した。なお結晶はい
ずれも非常に強い吸湿性を示した。また結晶とヨウ化メチルとを 反応させ，生成したヨウ化アンモニウムの隦点およひ同時に生じ たシチオール炭酸エステルによってアンモニウム塭を確認し，そ の結果は表 5 に示した。

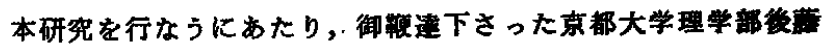
良造教授，および元笔分析に御協力いただいた京都大学化孚研究 所国近研究室の方々にそれぞれ感媩する。

20) C. W. Pifer, E. G. Wollish, Anal. Chem., 24, 300 (1952).

\title{
無水フタル酸とカルボン酸ヒドラジドとの反纫
}

(昭和 41 年 6 月 13 日受理)

卯西昭信*1

無水フタル酸とカルボン酸とドラジドとの反応を示差鷦分析と䓡重量分析で検副した。

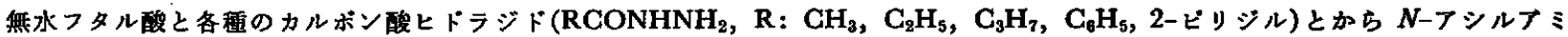
ノフタルイミド(I)の合成を試みた。第 1 段階怔無水フタル酸とカルボン酸ヒドラジドとから発熱反店により1-フシルー2-(oーカル

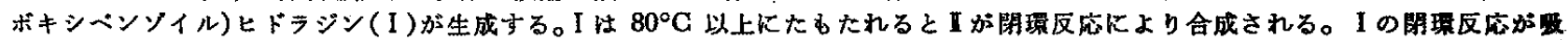

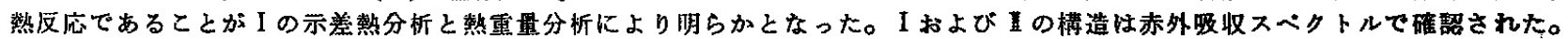

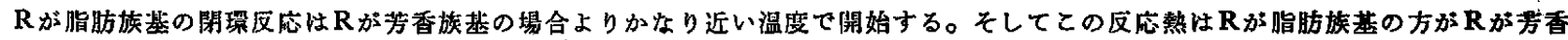
族基の埸合より大きい。

\section{1 緒 論}

皿水フタル酸とカルボン酸ヒドラジドとの反応については, Fox および Gibas'1よよって N-アシルアミノフタルイミドが合 成できるとの見解を発表しているが，その詳細な説明および実験 的解説はなされていない。

本研究では，無水フタル酸とカルボン酸ヒドラシドとの反応で 得られる 1-アシロイル-2-(o-カルボキシベンゾイル)ヒドラシド (I)を閉環させて $N$-アシルアミノフタルイミド(II)を合成した。 なおIを分離せずに直接】を合成した。IおよびIについて示差 熱分析および熱テンビン特性曲線を測定し，IょりIの閣等反応 は吸熱反応であり，閉環反応の反応温度について檢討し，苔千の 知見を得たので報告する。

\section{2 実験}

\section{1 客 媒}

2.1 .1 ベンゼンの精製: ベンゼンは市販特級品をナトリゥム 金属で脱水し，使用するときはビン中から直接注射器で趿入し， 水分を吸取しないようにして用いる。

2.1.2 ジメチルアセトアミド(DMA)の棈製: 市販 1 級の DMA に五酸化りンを加え，24 時間以上放置後, 乾燥窒茭気流中で 2 回減圧蒸留を行なって用いた。使用方法はベンゼンと同じように 行なう。

*1 Terunobu UNISH 䄍非大学工学部工莱化学科, 蝎井市 牧島朾

1) H. H. Fox, J. T. Gibas, J. Org. Chem., 18, 1375 (1953).
2.1.3 無水フタル酸の棈製: 市販無水フタル酸を 無水暗酸か ら再結晶し，これを減圧下で昇華ざせ精した。

2.1.4 カルボン酸ヒドラジドの合成：カルボン酸アルキルエ ステルとヒドラジン水和物とから通常の方法2で合成し，得られ たカルボン酸ヒドラジドの虽点はつぎのと戊りで文献颠と一政し た。

$\left.\mathrm{CH}_{3} \mathrm{CONHNH}_{2} \mathrm{mp} 66^{\circ} \sim 67^{\circ} \mathrm{C}^{2}\right), \mathrm{C}_{2} \mathrm{H}_{3} \mathrm{CONHNH}_{2}$ mp $\left.38^{\circ} \sim 40^{\circ} \mathrm{C}^{3}\right), \mathrm{C}_{3} \mathrm{H}_{7} \mathrm{CONHNH}_{2} \mathrm{mp} 43^{\circ} \sim 44.5^{\circ} \mathrm{C}() ; \mathrm{G}_{6} \mathrm{H}_{5} \mathrm{CO}$

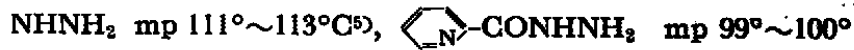
$\mathrm{C}^{6)}$ 。

\section{$2.2 N$-アシルアミノフタルイミドの合成}

2.2.1N-アセチルアミノフタルイミド：酷酸とドラシド $1.6736 \mathrm{~g}(0.02259 \mathrm{~mol})$ と無水フタル酸 $3.3462 \mathrm{~g}(0.02259 \mathrm{~mol})$ を 混合し, これに DMA $4.5 \mathrm{ml}$ を加え, $110^{\circ} \sim 120^{\circ} \mathrm{C}$ で 6.0 時 間たむったのち 1 夜放圈する。生成した針状結晶を口過し，口液 を減圧蒸留し，溶媒を留去する。球留物を洗浄する。針状桔晶と

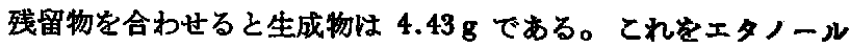
で再結晶する。 $\mathrm{mp} 221^{\circ} \sim 223^{\circ} \mathrm{G}_{\text {。 }}$ 同様にして各㗑の $N$-アシル

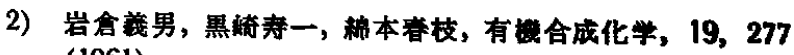
(1961).

3) F. K. Beilstein, "Handbuch d. Org. Chim", 2, 247 (1920).

4) F. K. Beilstein, "Handbuch d. Org. Chim", 2, 276 (1920).

5) F. K. Beilstein, "Handbuch d. Org. Chim", 9, 319 (1926).

6) F. K. Beilstein, "Handbuch d. Org. Chim ", 22, 35 (1935). 


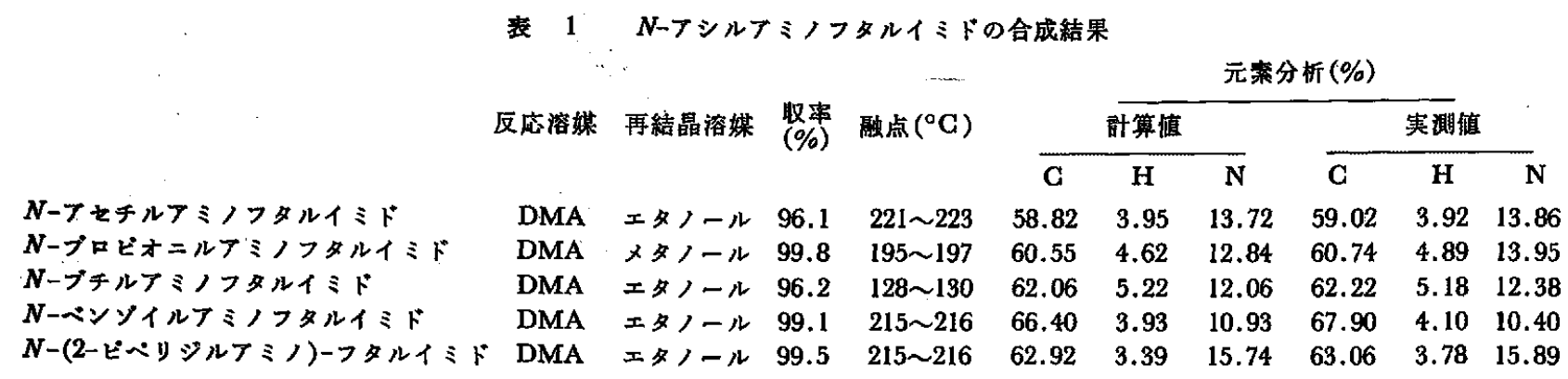

表 2 1-アシロイル-2-(0-カルポキシベンゾイル)ヒドラジンの合成結果

1-フセチル-2-(のーカルボキシベンゾイル)ヒドラジン 1-プロピオノイル-2-(oーカルボキシベンソイル)ヒドラジン 1-ブチロイルー2-(oーカルボキシベンゾイル)飞ドラジン 1ーベンゾイル-2-(0-カルボキシベンソイル)ヒドラジン 1-(2-ピロリソイル)-2-(o-カルボキシベンゾイル)ヒドラジン

\begin{tabular}{|c|c|c|c|c|c|c|c|}
\hline \multirow{3}{*}{ 反応溶媒 } & \multirow{3}{*}{$\begin{array}{l}\text { 肾率 } \\
(\%)\end{array}$} & \multicolumn{5}{|c|}{ 元素分析 (\%) } & \\
\hline & & \multicolumn{3}{|c|}{ 棓算做 } & \multicolumn{3}{|c|}{ 実䁌值 } \\
\hline & & $\mathbf{G}$ & $\mathbf{H}$ & $\mathbf{N}$ & C & $\mathbf{H}$ & $\mathbf{N}$ \\
\hline ベンゼン & 93.9 & 54.05 & 4.54 & 12.60 & 53.55 & 4.84 & 12.45 \\
\hline ベンゼン & 99.2 & 55.93 & 5.12 & 11.86 & 55.12 & 4.63 & 11.35 \\
\hline ペンゼン & 99.6 & 57.60 & 5.64 & 11.20 & 57.40 & 5.36 & 11.05 \\
\hline ヘンビン & 98.6 & 65.69 & 4.41 & 10.21 & 65.07 & 4.72 & 9.95 \\
\hline ジンビン & 99.1 & 51.94 & 3.89 & 14.73 & 51.53 & 3.99 & 14.57 \\
\hline
\end{tabular}

アミノフタルイミドを合成したがその結果を表 1 亿示した。

\subsection{1-アシロイル-2-(o-カルボキシベンゾイル) ヒドラジンの}

\section{合成}

2.3.1 1-アセセチル-2-(o-カルボキシベンゾイル) ヒドラジン: 酢酸ヒドラシド $0.7114 \mathrm{~g}(0.009603 \mathrm{~mol})$ と無水フタル酸 1.4223 $\mathbf{g}(0.009603 \mathrm{~mol})$ をベンゼン $15 \mathrm{ml}$ 中に加えかきまぜる。ただち に発熱反応する。2 時間室温でがきぜたのち, 口過し， $10 \mathrm{ml}$ のベンゼンで 2 回, $10 \mathrm{ml}$ の水で 1 回洗浄する。生成物 $2.00 \mathrm{~g} 。$ 同様にして各種の 1-アセキル-2-(0-カルボキシベンゾイル)ヒド ラジンを合成したがぞの結果を表 2 亿示した。

\section{4 熱テンビンおよび示差熱分析による熱分析}

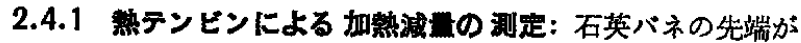
カギ状になった数本のガラス棒をつなぎ合わせ, さらにガラス棒 の下端に精科した試料 $0.100 \mathrm{~g}$ 入り白金ザラを電父炉の中央に 位置するようにつるす。試料を入れたのち， $300^{\circ} \mathrm{C} / \mathrm{hr}$ の昇温速 度で师内の温度を上げ試料の重量減少によるバネ絠みを 5 分ごと にカセトメーターで鿁む。石英バネ定数は, 化学テンビン用分銅 を用いて求め，この関係から試料の重量娍少率を計算する。

2.4.2 示差整分析: 装置は島津示差熱分析装置 DT-10 型を 使用し，試料は白金七ル $(50 \mathrm{~mm}$ 径，18 mm 長さ)にとり，図 1 に示すように試料側セルの中央部に試料約 $0.04 \mathrm{~g}$, 上下にアル ミナ約 $0.7 \mathrm{~g}$ を充テンする。笝準側セルにはアルミナのみを充 テンする。増幅感度は $\pm 25 \mu \mathrm{V}$ 。昇温速度 $300^{\circ} \mathrm{C} / \mathrm{hr}$ で空温よ り $240^{\circ} \mathrm{C}$ まで空気雾囲気中で測定を行なう。

\section{3 結果および考察}

無水フタル酸とカルボン酸ヒドラシドとを $10^{\circ} \sim 15^{\circ} \mathrm{C}$ で反応 させると発整反応して 1-アシロイルー(2-oーカルボキシベンゾィ

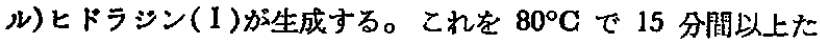
もつと完全に閉環反流が准行して $N$-アシルアミノフタルイミド (I)になる。

Iを坐成させずに Iのみを合成する場合，反応温度を $15^{\circ} \mathrm{G}$ 以 下にたもつ必要がある。Iのみを合成する条件では， Rがメチル

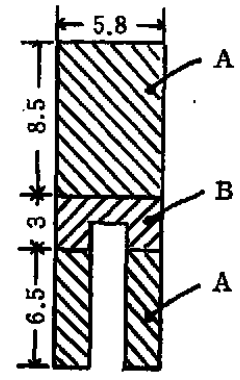

単位: $\mathrm{mm}$

$\mathrm{A}:$ フルミナ, $\mathrm{B}$ : 試料

図 1 試料側セル充テン状㖵<smiles></smiles>

R: $-\mathrm{CH}_{3}, \quad-\mathrm{C}_{2} \mathrm{H}_{5},-\mathrm{C}_{8} \mathrm{H}_{7},-\left\langle\sum_{n=}^{-}\right\rangle$

基の場合は，末反応の原料が一部残存する。反応系中に水が存在 すると生成物中にフタル酸が混入するのが認められた。無水フタ ル酸とカルポン酸とドラジ゙を溶媒中， $80^{\circ} \mathrm{C} て 15$ 分間たすつ とIが直接合成され，その收量にほぼ定量的である。Iをアルコ ールまたは水で再結晶を行なうと䦥䍗しI となる。

\section{1 赫外吸叹スペクトル}

I はヒドラジドのルボ二ル基に基づく吸収が 1600 １700 $\mathrm{cm}^{-1}$ が存在し，イミド環の特性吸収のある $1800 \sim 1750 \mathrm{~cm}^{-1}$ 亿は吸収が存在しない。またカルボキシル基の -C-O-の伸縮振 
動は 1320〜1211 $\mathrm{cm}^{-1}$ に強い吸収が知られている》。これに相当 する $1300 \mathrm{~cm}^{-1}$ の樶取が存在する。一方フタルイミドの $=\mathrm{C}=\mathrm{O}$ の特性吸収については 1739 と $1786 \mathrm{~cm}^{-1}$ 亿 2 本知られている8。 Iを閉環するとこれに相当する吸收が，わずか短波長にずれたと ころに, 新しく 1750 と $1800 \mathrm{~cm}^{-1}$ K生じる。これと同時に $-\mathrm{COOH}$ の $1300 \mathrm{~cm}^{-1}$ 付近の吸収は消失する。

\section{2 示差熱分析および熱テンビン特性曲綝}

I のRがエチル基の場合の示差熱分析曲線を図 2 に示す。

II $\mathbf{R}$ がエチル基の示差熱分析曲線を図 3 に示す。

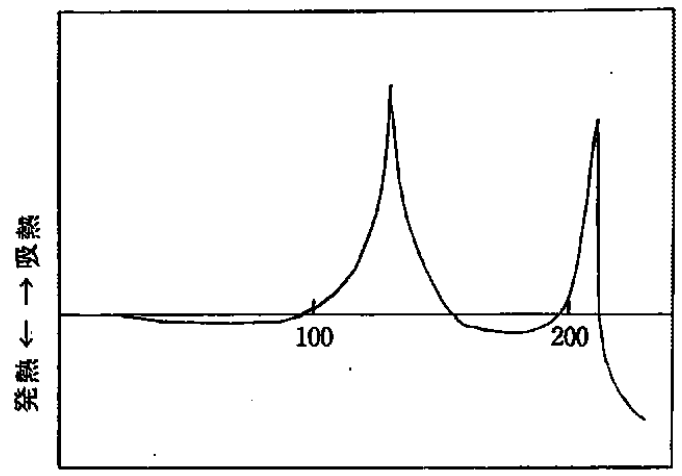

温度 $\left({ }^{\circ} \mathrm{C}\right)$

図 2 I , $\mathrm{R}=\mathrm{C}_{2} \mathrm{H}_{5}$ の示差熱分析曲線

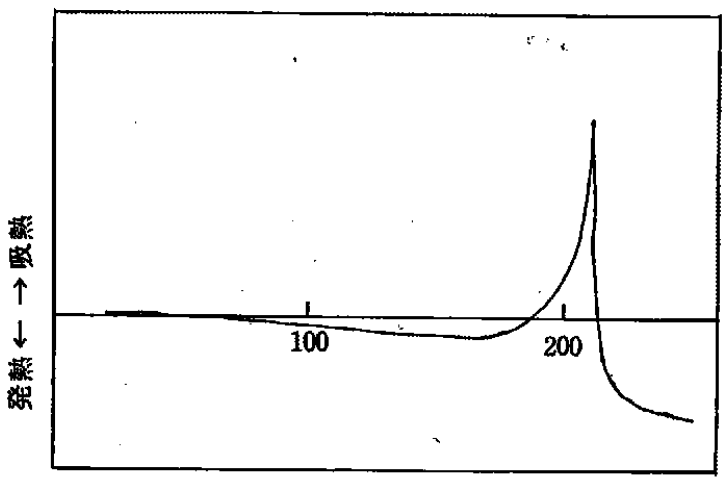

温度 $\left({ }^{\circ} \mathrm{G}\right)$

図 3 II, $\mathrm{R}=\mathrm{C}_{2} \mathrm{H}_{5}$ の示差熱分析曲線

$195^{\circ} \sim 210^{\circ} \mathrm{C}$ における 吸熱現象柱融解に基つく吸熱現象之考 えられる。すなわち図 2 と図 3 の $200^{\circ} \mathrm{C}$ 付近の吸熱現象の生じ る位睓は一致している。これは I が室温から溸次加熱されてくる 途中で閉環反応が起り【となり，同一の融点を示じたものと考 えられる。Iを毛管法でその融点を測定した場合, 湜度上昇をゆ っくりすると前記融解に基うく吸熱現象を示す位置とほ汪同じと ころで融解する。このように I は融解前に閉環反応を起すのでそ

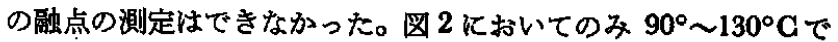
吸熱現象を示す。この点につき熱テンビン特性曲線とともに検討 する。

I でRがエチル基の熱テンビン特性曲線を図 4 に示す。

$100^{\circ} \sim 140^{\circ} \mathrm{G}$ でゆるやかにその減少が認められる。この範囲 は示差熱分析を行なったときの最初に吸熱現象を示す範囲とほほ

7) L. J. Bellamy, “The Infra-red Spectra of Complex Molecules", Methuen(1958)p. 162.

8) L. W. Kissinger, H. E. Ungnade, J. Org. Chem., 23, 815(1958).

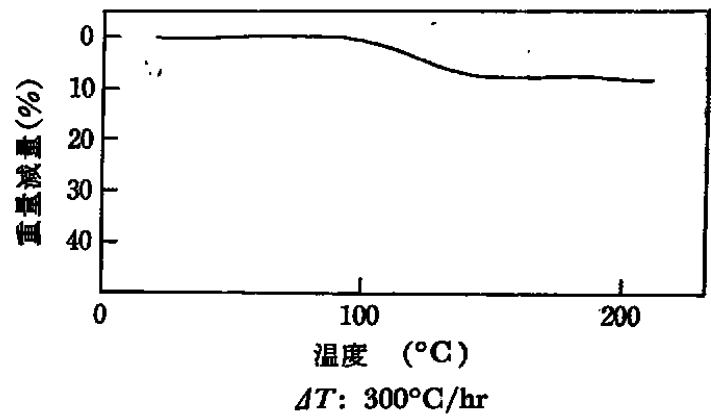

図 $4 I, R=\mathrm{C}_{2} \mathrm{H}_{5}$ の熟テンビン特性曲線

一致している。その咸少量は I 水 1 分子量に相当する。これら の結果から $5^{\circ} \mathrm{G} / \min$ の界温速度で加熱する閉溇反応は 90 $130^{\circ} \mathrm{C}$ で行なわれると考えられる。またアルコールや水ととも に加熱してる閉環反応が進もことを考えると，昇温速度を変える と閉罯反応が行なわれる温度範囲もわずか変わるものと考えられ る。

つぎに閉環反応が $\mathbf{R}$ 基の種類により変わるが同一条件下の示差 熟分析の結果を示す。

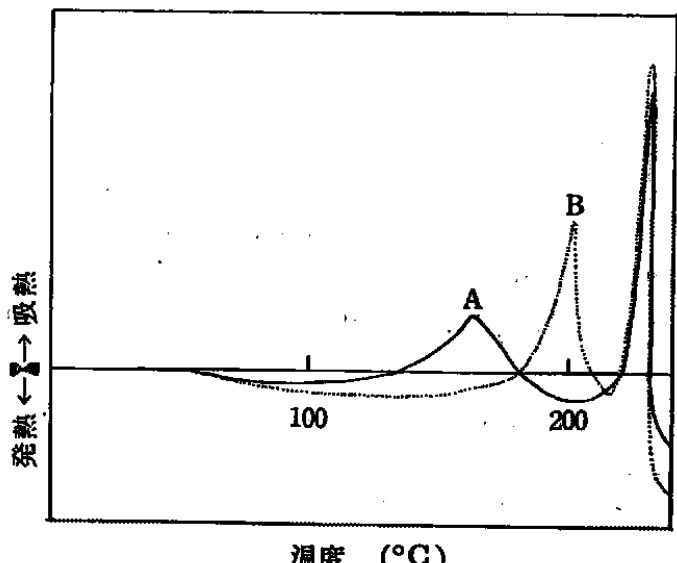

図 $5 \mathrm{I}, \mathrm{R}=\mathrm{C}_{6} \mathrm{H}_{5}(\mathrm{~A})$ と $\mathrm{R}=-\mathrm{N} /(\mathrm{B})$ の示差熱分析曲繶

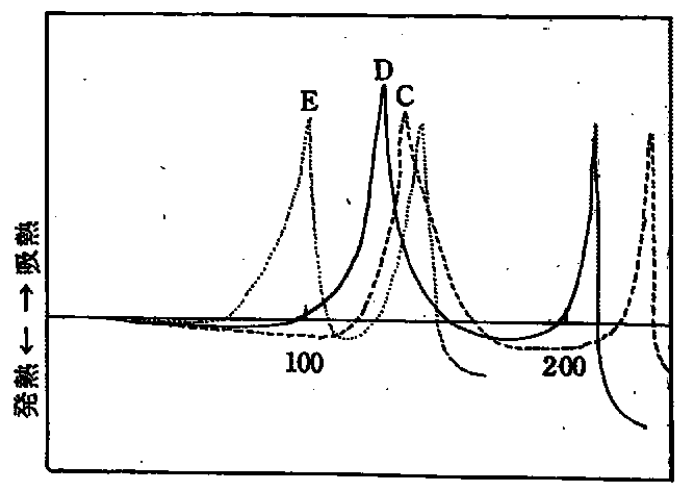

温度 $\left(^{\circ} \mathrm{C}\right)$

図 $6 I, R=C_{3}(G), R=G_{2} H_{5}(D), R=C_{8} H_{7}$ (E) の示差熱分析曲線

閉環反応は $\mathrm{R}=\mathrm{C}_{6} \mathrm{H}_{5}$ の場合 $130^{\circ} \sim 165^{\circ} \mathrm{G}, \mathrm{R}=\gamma_{\mathrm{N}}>$ の等合 $180^{\circ} \sim 200^{\circ} \mathrm{G}$ で起り，ともに $\mathrm{R}$ が脂肪族基の場合より离い温度 で進行する。 $\mathrm{R}$ が脂肪族基のときは $90^{\circ} \mathrm{C}$ 付近より $130^{\circ} \mathrm{C}$ 付 近で起り，炭素鎖によりほとんど差異が認められながった。 
示差熱分析を行なうときにサンプル側セル中に入れた試料の最 をほぼ一定にたすった。したがって曲線の吸熱の山岀の面唋が，そ の反応魹の大小にほほ比例ているものと考光られる。図 5 および 图 6 の結果から吸熱量は譄肪族基>ー がわかる。
本研究のー・部は通偟省工業技術院繳維工莱訊験所で行なったも のであることを付眍する。

本研究にあたり御指導いただいた東京工莱大学教授岡猗光雄教 授に樑謝致します。また示差熱分析の測定および制論をいただい た工業技術院㑘維工業試験所金網久明技官に战謝いたします。

(1966 年 4 月, 日本化学会第 19 年会講演)

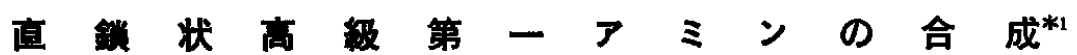

（昭和 41 年 6 月 13 日 受理）

\author{
後藤 良造*2 $\cdot$ 渡辺明*3 $\cdot$ 北条 剛*2 $\cdot$ 高坂 裙夫*3
}

直鎖状化合物の炭共数の增加にとむなう物理的性質の相互関係を明らかにする目的で，これまでほとんど合成のなされたことが

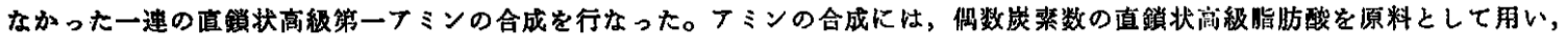
偶数フミンは酸丁ミドを水菜化フルミニウムリチウム $\left(\mathrm{LiAlH}_{4}\right)$ にって遄元して，また奇数てミン酸フミドの Hofmann 分解，

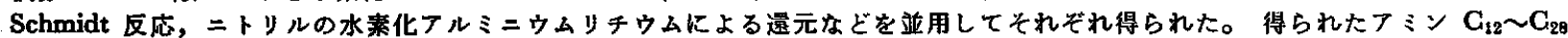

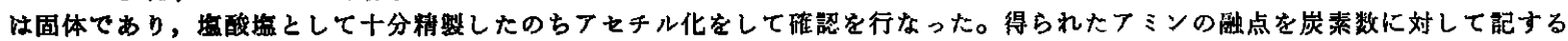
とき，明らかに交互甠のある曲線が見られた。同様にフセチル化したてミンむ融点曲維を得た。

\section{1 緒咅}

長鎖状化合物の合成，およびその菜列に対与る物性の研究とし ては，これまでパラフィン，睃，アルコール，真化物などについ て，およそ炭索数 30 愔までの化合物関する研究が行なわれて いる。最近，著者らは， $\mathbf{C}_{12} \sim \mathrm{C}_{37}$ の直鎖状第一アルコールを合 成して，そのX線的研究》と赤外吸収スペクトルに関する研究2) を行なった。

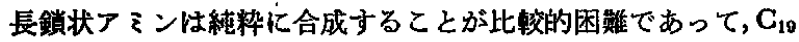
以上の化合物はまだ合成されていない。また，一般に系統的な物 性研究はほとんど行なわれていないる。著者らはアミンの系列を できるだけ純粋に合成して，他の長鎖状化合物，とくに高級アル コールの物性と比較する目的で， $\mathrm{G}_{12} \sim \mathrm{C}_{28}$ の直鎖状第一ア之 ンを合成した。物性の研究は, 融点および転移点の鎖長依存性, 常温および高温(融点下)における構造などを対象とする。合成の 出発物質としては脂肪酸を用い，そのうち低級なるのは本販品を 十分に精製し，高級なるのは臭化アルキルから，マロン酸エステ ル合成法, ニトリル合成法によって合成した。またオクタコサン 酸 $\left(\mathbf{C}_{28}\right)$ は，オクタデシルマグネシウムブロミドを，塩化亜鉛を 用いて，9-カルベトキシノナン酸クロリドと維合させて，9-ケト オクタコサン酸を得りこれ化 Kishner 選元を行なって合成し

*1この報交を“長鎖状化合物の合成と物性(第 1 報)”とす る.

*2 Ryozo Goto, Ko Hojo 京都大学理学部化学科有機化 学教空, 京都市左京区北白川追分町

*3 Akira WATANABE, Masao KOSAKA 立命館大学理工学 部化学科有機化学数室, 京都市北区等持院

1) A. Watanabe, Bull. Chem. Soc. Japan, 34, 1729(1961); 36, 336(1963).

2) T. Shimanouchi, R. Goto, et al., Spechrochim. Acta, 20, 629(1964).

3) 磷電草の研究として, C. P. Smyth, et al., J. Am. Chem. Soc., 71, 3591(1949).

4) R. G. Jones, ibid., 69, 2350(1947).
$た^{-3)}$ 。

$$
\begin{aligned}
& \mathrm{C}_{18} \mathrm{H}_{37} \mathrm{MgBr} \longrightarrow\left(\mathrm{C}_{18} \mathrm{H}_{37}\right)_{2} \mathrm{Zn} \\
& \left(\mathrm{C}_{18} \mathrm{H}_{37}\right)_{2} \mathrm{Zn} \longrightarrow \mathrm{ClOC}\left(\mathrm{CH}_{2}\right)_{8} \mathrm{CO}_{2} \mathrm{G}_{22} \mathrm{H}_{5} \\
& \mathrm{C}_{18} \mathrm{H}_{37} \mathrm{CO}\left(\mathrm{CH}_{2}\right)_{8} \mathrm{CO}_{2} \mathrm{C}_{2} \mathrm{H}_{5} \longrightarrow \mathrm{C}_{18} \mathrm{H}_{37} \mathrm{CH}_{2}\left(\mathrm{CH}_{2}\right)_{8} \mathrm{CO}_{2} \mathrm{H}
\end{aligned}
$$

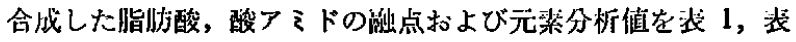
2 に示す。

高䋌第一アミンの合成については，これまで，(1)ヨウ化アル キルの Gabriel 区応6)，(2)脂肪酸アミドをエーテル中で水絜化 アルミニウムリチウムで辜元する方法》，(3)ニトリルをエーテ

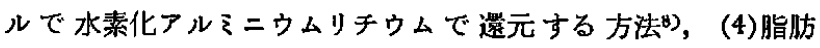
酸アミドのメタノール中における Hofmann 分䑾》, (5)脂肪酸 の Schmidt 反応10)，などが知られている。著者らは偶数アミン の合成として， $\mathbf{C}_{18}$ 扰よび $\mathbf{G}_{22}$ のヨウ化物に(1)の反応を試みた が好結果を得ることができなかった。そとてで(2)の反応を用いた が，脂肪酸アミドの鎖長が長くなるとエーテルに難溶となり，ま た収率もいちじるしく低下することがわかったので，溶媒をテト ラヒドロフランにかえた結果, 最高炭素数 $\left(\mathrm{C}_{28}\right)$ の場合にも, 好 収率で目的物を得ることに成功した。

$$
\mathrm{RCONH}_{2} \stackrel{\text { LiAlH}}{\longrightarrow} \mathrm{RCH}_{2} \mathrm{NH}_{2}
$$

一方, 奇数アミンの合成には，(3)，(4)，(5)の方法を用いた。 とくに(5)の Schmidt 反応は, 脂肪酸から直接アミンを得る方法 として，操作も簡粆であって収率もよい。したがって， $\mathbf{C}_{27}$ およ び $\mathrm{C}_{23}$ のアミンをこの方法で合成した。

$$
\mathrm{RCH}_{2} \mathrm{CO}_{2} \mathrm{H} \stackrel{\mathrm{HN}_{3}}{\longrightarrow} \mathrm{RCO}_{2} \mathrm{H}+\mathrm{CO}_{2}+\mathrm{N}_{2}
$$

アミン系列の合成結果を表 3 に示す。

5) Huang Minlon, J. Am. Chem. Soc., 68, 2487(1946).

6) E. T. Borrows, et al., J. Chem. Soc., 1947, 199.

7) L. M. Brown, et al., J. Am. Chem. Soc., 77, 1684 (1955).

8) R. F. Nystrom, W. G. Brown, ibid., 70, 3738(1948).

9) L. Jeffrey, et al., J. Biol. Chem., 59, 905(1924).

10) L. H. Briggs, et al., J. Chem. Soc., 1942, 1963. 